\title{
Professional Performance of The First Middle School Teacher in School Head Master Management
}

\author{
Deti Rostini ${ }^{1}$, Otto Fajarianto ${ }^{2}$, Umi Fatonah ${ }^{3}$, Mesra Betty Yel ${ }^{4}$

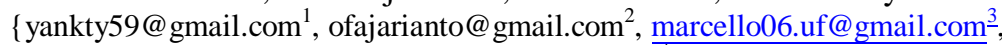 \\ mey.mesra@yahoo.com ${ }^{4}$ \}
}

Universitas Islam Nusantara, Bandung, Indonesia ${ }^{1}$, Universitas Swadaya Gunung Jati, Indonesia $^{2}$, Universitas Ibn Khaldun Bogor, Indonesia ${ }^{3}$, STIKOM CKI, Jakarta, Indonesia ${ }^{4}$

\begin{abstract}
Development of Professional Performance Teachers are always considered in the world of schooling education given the weak performance of teachers, the lack of participation of teachers in carrying out their duties, still only a routine without change both in strategy, methods, techniques, media, and others, as well as issues regarding the role of the Head school as a motivator and manager in human resource management that does not work as it should. The purpose of the study was to find out the description of the professional development of teachers in the management of principals in state junior high schools in Cipongkor sub-district, West Bandung District. The approach theory used in this research was a naturalistic qualitative approach. While the solution to overcome it can be done by the principal in implementing a guidance system for teachers so that the quality and performance of teachers can be improved. Management of teacher professionalism fostering is the right step to overcome this problem. The steps that can be taken are the school principal and his staff to make plans for coaching, organizing, implementing guidance, and evaluating the results of coaching.
\end{abstract}

.Keywords: Development Theory, Professional ,Principal Management

\section{Introduction}

The teacher is the front guard in education, the teacher is a professional educator with several main tasks of educating, teaching, guiding, directing, training, assessing, and evaluating. The main task of a teacher will be effective if the teacher has a high degree of professionalism which is reflected in four teacher competencies he has. The four competencies that must be possessed by a teacher are professional competence, social competence, personality competence, and pedagogic competence.

Professional competence can be interpreted as a teacher's skill in delivering teaching material to students he faces. This competence is seen in a teacher, if he can create effective, efficient, fun learning. Supported by methods that are relevant to teaching materials, as well as the delivery of learning that is not boring. The most important professional teacher can motivate students to be passionate about learning. This is important because professional competence is closely related to planning and implementing learning in teaching and learning activities.

According to Syaodih (1988) teachers play an important role both in planning and curriculum implementation. Teachers are planners, implementers, and curriculum developers for their 
class. In addition the teacher also acts as an evaluator and completes the curriculum. Realizing this is how important it is to increase teacher activity, creativity, quality and professionalism.

Teachers who meet the criteria of professionals are expected to be able to carry out their main functions effectively and efficiently to realize the process of education and learning in achieving national education goals, namely: "The development of the potential of students to be faithful, devoted, noble, healthy, knowledgeable human beings. , capable, creative, independent, and responsible".

Professional principals will implement the vision and mission into action. Vision and mission are not just meaningless slogans to a professional school principal. The function and role of the principal as an educator, manager, administrator, supervisor, leader, innovator, and motivator are truly run by a school principal who has competence.

At a school principal who has competence, SWOT analysis can easily be done SWOT Analysis The scope of the research on teacher professionalism development is based on the limitations of the problems in the management of the principal, namely planning, organizing, implementing, and evaluating. With the aim of knowing the description of the professionalism performance of teachers in the management of principals in West Bandung District Junior High School.

\section{Theoretical Basis}

\section{a. Teacher Profession}

According to Dedi Supriyadi (1999) states that teachers as a profession in Indonesia is new in the growing level (emerging profession) whose level of maturity has not yet reached what has been achieved by other professions, so the teacher is said to be a semi-professional or semi-professional profession.

Professional work is different from non-professional workers because a profession requires special skills and expertise in carrying out their profession in other words professional work is work that can only be done by those who are specifically prepared for it.

Teacher professional development must be recognized as a very fundamental and important thing to improve the quality of education. Professional development is the process by which teachers and principals learn, improve and use knowledge, skills and values appropriately.

The teacher profession has the task of serving the community in the field of education. The demands of this profession provide optimal services in the field of education to the community. In particular teachers are required to provide professional services to students so that learning objectives are achieved. So that the teacher who is said to be professional is a person who has special abilities and expertise in the field of teacher training so that he is able to carry out his duties and functions as a teacher with maximum ability.

\section{b. Headmaster Management}

According to Burhanudin (1990:530) said that the skill is commensurate with the word skill, and intelligence is called skill. Meanwhile, managerial is an adjective related to leadership and management. In many libraries, managerial words are often referred to as the origin of words from management which means training horses or literally interpreting as to handle which means taking care, handling, or controlling. Meanwhile, management is a noun that can mean management, governance or management. In principle, the definition of management has the following characteristics: (1) there are objectives to be achieved; (2) as a combination of science and art; (3) is a systematic, coordinated, cooperative and integrated process in utilizing its elements; (4) there are two or more people working together in an organization; (5) based on the division of labor, duties and responsibilities; (6) includes several functions; (7) is a tool to achieve goals. 
According Wahjosumidjo (2002: 4) suggests that the description of the duties and responsibilities of the principal can be seen from two functions, namely the principal as an administrator and as a supervisor. The principal as an administrator at the school has duties and responsibilities for all managerial processes that include planning, organizing, mobilizing, and supervising all fields of work which are the responsibility of the school. The management field can include the fields of personnel, students, administration, curriculum, finance, facilities and infrastructure, school and community relations and other supporting units.

Whereas, the principal as a supervisor is concerned with service activities towards improving the professionalism of teachers in order to achieve a quality learning process. To be able to carry out these tasks and responsibilities, the principal needs to have the various abilities needed. According to Katz, managerial abilities include technical skills, human skills, and conceptual skills. Technical ability is the ability that is closely related to the use of tools, procedures, methods and techniques in a management activity properly (working with things). Meanwhile, human relations ability is the ability to create and foster good relationships, understand and encourage others so that they work voluntarily, no compulsion and are more productive (working with people). Conceptual ability is the mental ability to coordinate, and integrate all the interests and activities of the organization. In other words, this conceptual ability is related to the ability to conceptualize (working with ideas) about various things in the institution he leads (Wahjosumidjo (2002: 14).

Along with the change in the paradigm of decentralization of education and autonomy of schools / madrasas with the enactment of a school based management management model, the principal as the top management in schools has a very important and strategic position. Even according to the results of a study from Lipham, it is stated that the success of a school (madrasah) is very much determined by the ability of the madrasah / school head to manage and lead the institution.

\section{Method}

The method used is a qualitative method with a descriptive approach, according to Nasution (2006: 63) "Descriptive research is called data collection activities to give an idea or idea of a concept or symptom. With the technique of data collection, observation, interviews and documentation studies. With the location of research in Cipongkor District Middle School, West Bandung District. The research subjects selected as samples were considered to represent the entire research subject. Research subjects are needed as a source of data and information. While the data collection procedure for qualitative research is grouped into three groups: orientation stage, exploration stage, member check stage.

\section{Result and Discussions}

Fostering teacher performance is an important point in efforts to improve teacher professionalism in schools. Although the method of school in an effort to improve teacher performance has a difference in the method, but basically the effort to foster teacher performance leads to the same substance. In the planning stage in an effort to foster teacher performance in schools, according to the results of interviews and observations. Public junior high schools conducted include: the preparation of the school's vision and mission, the preparation of school objectives, the preparation of school objectives, school self-evaluation (EDS), the annual school program, and RKAS. 
Guidance and assessment of teacher performance refers to the school's selfevaluation, it will show the goals and programs that have not been achieved, so that the preparation of the improvement program and the development of performance can be improved in the current year or the following year. The stage of organizing performance coaching so that the implementation of coaching will be clear in the direction of the teacher, and in accordance with what is expected. So first made or appointed coordinator of the assessment of sustainable performance in this program. Organizing under the command of the principal is determined through a special meeting that involves all stakeholders in the school at the Stage of Teacher Performance Development.

The guidance and performance appraisal system that occurs in the SMP is carried out after an agreement between the teacher and the head, or between the teacher and supervisor, or between the new teacher and senior teacher. At the implementation stage before the observation is conducted, the principal holds a special meeting with the teacher. Here the matters related to the availability of supporting documents in the framework of the implementation of teacher performance assessment are stated, the schedule for the implementation of teacher performance assessment, as well as the report format that will be used as the final evaluation in the implementation of teacher performance.

The implementation of other coaching carried out in SMPNs in order to improve teacher performance, among others, is to send educational staff in this case the teacher to attend an education or training program. The education program is directed at those who do not have a Bachelor level (S-1) education, the education taken must be linear with the subjects that they receive.

\section{a. Discussion}

The discussion of the results of the study is to summarize the research description associated with the relevant theory to be used as material in drawing conclusions.

1) Preparation of Principal Planning in Teacher Performance Management

Planning can be arranged based on the steps that will be carried out to achieve the stated goals. Planning can be arranged based on needs within a certain period of time in accordance with the wishes. The more important planning is made so that it can be implemented easily and on target.

2) Tahap Pengorganisasian Kepala Sekolah dalam pembinaan Kinerja Guru

In order for the teacher performance improvement program to run according to what was planned. First, the organizational structure is arranged so that what, who, and when the program must run, the organizational structure that is made is adjusted to the situation and conditions at that time. Organizational structure formation procedures are needed so that the goals of what is planned are clear. The goals are achieved effectively and efficiently. At this stage teacher performance development activities are formed which consist of stakeholders in the school, among others: the headmaster, the organizing committee chairman in this case is the assistant to the principal, secretary, and senior teachers.

3) Stage of Implementation of the Principal in Teacher Performance Development Various efforts were taken by the principal in order to improve teacher performance. In both schools the implementation of teacher performance guidance is carried out by: 1) individual and group coaching; 2) participate in activities outside the school such as training, upgrading, equalization of diplomas, MGMP, workshops, IHT, seminars, mentoring curriculum, etc .; 3) adding facilities and infrastructure; 4) teacher performance evaluation (PK), 4) teacher supervision. In the context of applicative professional teacher skills can be realized in the mastery of the following competencies: 1) mastering the 
material; 2) can manage teaching and learning programs; 3) can manage classes; 4) can use media and sources; 5) mastering the foundation of education; 6) mastering teaching and learning interactions; 7) assessing student achievement; 8) recognize the function of counseling guidance services; 9) get to know the school administration; 10) understanding the principles of research results for teaching needs (Suryasubrata: 1997: 4). The above applicable context can be realized if the principal as a leader can provide guidance appropriately for the teacher who is his co-worker. Supervision activities are activities that must be carried out in the implementation of education. Implementation of supervision activities is carried out by school principals and school supervisors. This needs to be done because the teaching and learning process implemented by the teacher is at the core of the overall education process as the main role holder.

4) Principal Evaluation Phase in Teacher Performance Development

Purpose of the Principal in carrying out a performance assessment carried out by the teacher within one semester. Not to look for mistakes made by the teacher but to aim at assessing the teacher's ability to apply all the skills competencies needed in teaching and learning activities. Thus the teacher's performance as an illustration of the teacher's strengths and weaknesses will be identified as need analiasis or audit assessment skills also intended for planning sustainable professional development to calculate the credit figures obtained by the teacher for performance, for the implementation of additional tasks relevant to the school functions performed in that year if the teacher is a Civil Servant. Assessment of teacher performance is carried out every semester which includes; 1) pedagogic competence; 2) personality competence; 3) social competence; 4) professional competence

\section{Conclusion}

Based on the findings of the study there are several aspects of the findings, namely the good, effective and efficient managerial role of the principal has a positive impact on improving teacher performance. Through planned activities, organized, supervised, and evaluated, as well as follow-up, teacher performance development activities can foster enthusiasm, work ethic, and positive performance. Because the benefits will be felt both for the teacher concerned and for the principal.

a. In planning the development of teacher performance, the preparation was carried out beginning with an analysis of the problems faced by the teacher in learning, problems raised in school work meetings. Problems include the development of learning plans both syllabus and lesson plan, or in the form of the implementation of teaching and learning activities and the use of information technology.

b. In organizing it first begins by holding a teacher meeting for the preparation of the coordinator or committee for the development of teacher professional performance. The committee involves the principal, vice principal, responsible person, secretary, treasurer, and members.

c. The implementation of teacher performance guidance includes the implementation of teacher's and implementation outside the teacher's such as workshops, seminars, opportunities to continue their studies to the next level, upgrading, training, MGMP etc. 
d. Teacher performance evaluation activities by principals are carried out periodically in the form of planning evaluation, implementation evaluation, evaluation evaluation, and follow-up evaluation. Useful evaluation for the school principal to measure the achievement of the goals that have been set, as well as the material for preparing the work program in the following year. For the teacher, the evaluation becomes an improvement material and material consideration for promotion and class or promotion in addition to improving performance.

\section{References}

[1] Ali, M. (1992). Educational Research Strategy. Bandung: Space

[2] Arifin, D and Pipin Arifin. (2011). Professionalism of a Teacher. Bandung:Al-Kasyaf Reader

[3] Arikunto, S. (2006). Research Management. Jakarta: Rineka Cipta

[4] Bunyan. (2015). Managerial Role of Principals in Improving Teacher's performance. Uninus PPS S2 Thesis.

[5] Dadi, P and Daeng Arifin. (2010). The Smiling Teacher. Bandung: Nuance of Aulia

[6] Fredrick Taylor, W. Scientifick Management. (Happer and Breos). New York

[7] Manullang, A. A. (2013). Personnel Management. Medan: Ghalia Indonesia

[8] Moleong. (2007). Qualitative Research Methodology. Bandung: Rosdakarya.

[9] Mulyasa, E. (2002). School Based Management. Bandung: Rosdakarya

[10] Mulyasa, E. (2013). Become a Professional teacher. Bandung: Rosdakarya

[11] Mulyasa, E. (2009). Become a Professional School Principal. Bandung: Rosdakarya

[12] Nasution. (2006). Curriculum and Teaching. Bandung: Bumi Aksara

[13] Permana and Mulyana. 9225). Class management. UPI Bandung: Department Adpen

[14] Rahyubi. (2012). Learning Theories and Motor Learning Applications.Bandung: Nusa Media

[15] Sa'ud. (2008). Teacher Professional Development. Bandung: Alfabeta

[16] Sugiyono. (2013). Research Education Methods. Bandung: Alfabeta 